\title{
KETERLIBATAN KAUM INJILI DALAM DIALOG ANTAR UMAT \\ BERAGAMA: \\ SUATU REFLEKSI TEOLOGIS-PEDAGOGIS ATAS METODE DIALOG \\ "PASSING OVER"
}

Desi Sianipar

\begin{abstract}
Abstrak
Penulisan makalah ini dilatarbelakangi oleh pengamatan penulis mengenai kurangnya keterlibatan kaum Injili dalam dialog antar umat beragama, yang justru banyak dilakukan oleh kalangan Kristen lainnya. Hal ini disebabkan kaum Injili memiliki pemahaman teologis yang berbeda mengenai perjumpaan dengan agama-agama lain, dan kekuatiran mengenai akibat dari perjumpaan tersebut.
\end{abstract}

Berdasarkan pembahasan teoritis, tampak bahwa ada beberapa penyebab kaum Injili kurang terlibat dalam dialog antar umat beragama, yaitu: kekuatiran terjadinya sinkretisme melalui dialog; kekuatiran akan disalahmengerti mengenai keterlibatan dalam dialog; dialog tidak dibutuhkan dalam penginjilan, yang dibutuhkan adalah pendampingan pastoral Kristen; kekuatiran akan terjadinya kemunduran dalam penginjilan; dan sikap eksklusivisme dalam memandang agama-agama lain. Meski dalam posisi demikian, menurut penulis, sebenarnya keterlibatan kaum Injili dalam dialog antar umat beragama masih bisa dimungkinkan kalau mereka memahami dan menghayati keteladan Kristus dalam hal mengosongkan diri (kenosis) untuk mampu membuka diri terhadap orang lain.

Metode yang digunakan dalam penulisan makalah ini adalah metode kepustakaan di mana penulis menggunakan sejumlah literatur berbahasa Indonesia dan Inggris, yang membahas tentang dialog antar umat beragama dan keterlibatan kaum Injili dalam dialog antar umat beragama.

Selanjutnya, pembahasan dilakukan menurut tinjauan secara teologis pedagogis. Orang Kristen semestinya mampu terlibat dalam dialog antar umat beragama. Penulis mengusulkan suatu metode dialog "melintas batas" atau "passing over", yang kalau menerapkan prinsip kenosis, kaum Injili dapat melakukannya. Metode ini akan memampukan setiap orang mengalami pengenalan yang mendalam mengenai para penganut agama lain di mana orang tidak pindah agama atau keyakinan, dan bukan sedang dalam pencarian jati diri, 
juga bukan sedang mencoba-coba mencicipi rasa keagamaan yang lain. Dia melakukan dialog ini untuk memiliki pemahaman yang lebih dalam lagi tentang keyakinan orang-orang dalam agama lain, dan dengan itu justru akan memperkuat keyakinannya sendiri.

\section{Kata Kunci:}

Keterlibatan, Kaum Injili, Dialog, Passing Over

\section{Pendahuluan}

Penelitian ini dilatarbelakangi oleh pengamatan atas fenomena kurangnya minat kaum Injili untuk terlibat dalam dialog antarumat beragama sebagaimana yang banyak diutarakan oleh beberapa teolog, termasuk yang berasal dari kaum Injili sendiri. Misalnya dari kalangan Injili, Clark H. Pinnock menyatakan kalangan Injili cenderung mengabaikan dialog antarumat beragama karena sikap eksklusivismenya dan karena melihat bahwa tidak ada harapan bagi agama-agama lain untuk berubah. Tetapi menurut dia, Kongres Lausanne II tahun 1989 sudah menunjukkan adanya perubahan sikap yang mengarah pada keterbukaan dalam berdialog dengan agama-agama lain. ${ }^{120}$

Menurut Samuel dan Sugden, keengganan kaum Injili dalam berdialog dengan agama-agama lain setidaknya juga dipengaruhi oleh pernyataan Hendrik Kraemer dalam Konperensi Tambaram tahun 1938. Pada konperensi itu, Kraemer menyatakan bahwa ada diskontinuitas yang tajam antara agama-agama non Kristen dan penyataan Kristen. Dengan begitu, agama-agama non Kristen harus lenyap dan digantikan oleh penyataan Kristen. Ada empat pedoman yang dapat digunakan untuk proses mengembangkan penyataan Kristen di dalam kebudayaan-kebudayaan non Kristen, yaitu: (1) prinsip "evangelistic adaptation" di mana kebenaran Kristen harus dinyatakan sebagai yang bertentangan dengan konteks moral dan agama-agama non Kristen; (2) prinsip legitimasi berbagai inkarnasi dalam Kekristenan; (3) penggabungan unsur-unsur penyataan Kristen dengan ide-ide keagamaan pra-Kristen adalah sinkretistik; (4) sejarah adaptasi Kekristenan setelah masa PB pada umumnya bercampur dengan muatan sinkretisme. ${ }^{121}$

120 Clark H. Pinnock, "Toward An Evangelical Theology of Religions. JETS 33/3 (September 1990), 359-368. http://www.etsjets.org/files/JETS-PDFs/33/33-3/33-3-pp359368」JETS.pdf

121 Vinay Samuel \& Chris Sugden, “Dialogue with other religions: An Evangelical view", dalam Bong Rin Ro \& Ruth Eshenaur (eds.), The Bible \& Theology in Asia Contexts: An Evangelical Perspective on Asia Theology (Seoul, Korea: Word of Life Press \& Asia Theological Association, 1984), 265-289. 
Kaum Injili belum terlibat dalam dialog antarumat beragama karena empat hal, yaitu: kekuatiran terjadinya sinkretisme melalui dialog ${ }^{122}$; kekuatiran akan disalahmengerti mengenai keterlibatan dalam dialog; dialog tidak dibutuhkan dalam penginjilan, yang dibutuhkan adalah pendampingan pastoral Kristen; kekuatiran akan terjadinya kemunduran dalam penginjilan. ${ }^{123}$

Ketakutan akan terjadinya sinkritisme terasa begitu kuat pada Sidang Raya DGD ke-5 di Nairobi tahun 1975 dan telah menjadi salah satu yang dibahas kembali dalam pertemuan di Chiang Mai, Thailand, tahun 1977. Ketakutan itu telah dijawab dalam pedoman dialog antarumat beragama yang berhasil dirumuskan pada pertemuan itu dalam butir 24-29, bahwa masalah sinkretisme tidak boleh menghalangi orang Kristen untuk tetap berdialog. Orang Kristen harus berani mengambil resiko dalam dialog, meskipun harus tetap ada sikap kewaspadaan terhadap bahaya tersebut. Karena itu, diupayakan supaya ada penerjemahan pesan Kristen di setiap waktu dan tempat, yang tetap menjaga keotentikan makna maupun istilah yang digunakan dalam kehidupan dan iman Kristen. ${ }^{124}$

Menurut penulis, dalam lingkup Kekristenan, dialog antarumat beragama semestinya adalah kegiatan yang bisa dilakukan oleh setiap orang Kristen dari aliran doktrinal dan teologis apapun dengan bebas dan sukacita, tanpa keterpaksaan dan ketakutan tentang dan terhadap apapun. Dialog adalah bagian yang wajar dari kehidupan sebagai wujud perjumpaan dan komunikasi kita dengan orang lain (yang sepaham maupun tidak sepaham) maupun dengan diri kita sendiri. Dalam dialog, setiap orang bebas untuk tetap pada pendiriannya, tetapi juga bebas untuk mengakui dan menghargai orang lain yang tidak sama pendiriannya. Dalam hal ini saya setuju dengan pendapat Kautsar Azhari Noer bahwa sikap eksklusivistik yang menutup diri dalam dialog dengan kalangan lain bukan suatu petunjuk akan kekuatan imannya, tetapi justru menunjukkan kelemahan. Dalam konteks berdialog, ketertutupan adalah menunjukkan ketakutan, dan ketakutan itu adalah kelemahan. Sebaliknya, keterbukaan adalah menunjukkan keberanian dan itu adalah suatu kekuatan. Kekuatan dalam beriman pada seseorang justru terbukti saat dia berani berhadapan dengan orang-orang lain yang

122 World Council of Churches, Guidelines on Dialogue with People Living Faiths and Ideologies. Geneva: World Council of Churches, 1979), 14-15; Olaf H Schumann, Dialog antar umat beragama (Jakarta: BPK Gunung Mulia, 2008), 84-85.

123 Vinay Samuel \& Chris Sugden, “Dialogue with Other Religions: An Evangelical View". Dalam Bong Rin Ro \& Ruth Eshenaur (eds.), The Bible \& Theology in Asia Contexts: An Evangelical Perspective on Asia Theology (Seoul, Korea: Word of Life Press \& Asia Theological Association, 1984), 276-280.

124 World Council of Churches, Guidelines on Dialogue ... Ibid., 14-15. 
berbeda pandangan dengannya dalam satu agama maupun yang berbeda agama dengannya. ${ }^{125}$ Pada masa kini, mempertahankan identitas diri sendiri dan tetap bisa menghargai keyakinan para penganut agama lain bisa dimungkinkan melalui pendekatan teologi komparatif.

\section{A. Kajian Teori}

1. Identitas Kaum Injili

Secara umum diketahui bahwa penggunaan istilah Injili sebagai nama dari suatu gerakan Kekristenan mempunyai kerumitan tersendiri karena ada banyak kelompok atau gereja Kristen, khususnya di kalangan Protestan yang menggunakannya. Tetapi kaum Injili yang dimaksudkan di sini adalah suatu kelompok Kristen yang muncul sebagai reaksi yang keras terhadap sikap kalangan Fundamentalis pada tahun 1940-an. Gerakan ini muncul sebagai akibat perpecahan dalam tubuh gerakan Fundamentalisme Amerika yang bersifat radikal dan separatis dalam perlawanannya terhadap teologi liberal dan bentuk-bentuk pemikiran Pencerahan. Kaum Injili sendiri lebih memilih untuk memasuki dunia sekuler, mempengaruhinya dan berusaha mengubahnya. Pada awalnya gerakan ini disebut New atau Neo-Evangelical, kemudian disingkat menjadi "Evangelical" (Injili), yang dipimpin oleh Harold Ockenga. Semua organisasi yang tergabung dalam gerakan Injili ini terorganisir dalam satu lembaga yang disebut National Association of Evangelicals (NAE) yang didirikan tahun $1942 .{ }^{126}$

Dalam perkembangannya, kaum Injili telah menjadi gabungan dari bermacam-macam tradisi gerejawi, yaitu antara lain: tradisi Reformed, tradisi pietis arus utama (Metodis), gereja-gereja Kesucian, gereja-gereja Pentakostal, gereja-gereja Restorasionis, gereja-gereja Dispensasionalis, gereja-gereja warisan Reformasi Radikal (Mennonit dan Baptist Amerika), tradisi Free Church, dan gereja-gereja arus utama tertentu (dari aliran Lutheran dan Baptist). Selain itu, yang juga tergabung dalam kaum Injili adalah berbagai organisasi parachurch, lembaga-lembaga pendidikan teologi, dan lembaga-lembaga misi. ${ }^{127}$ Semua organisasi ini tergabung dalam persekutuan Injili sedunia yang disebut World Evangelical Fellowship

125 Kautsar Azhari Noer, "Passing Over": Memperkaya Pengalaman Keagamaan", Dalam Hidayat, Komaruddin \& Ahmad Gaus AF (eds.), Passing Over: Melintasi Batas Agama (Jakarta: Penerbit PT Gramedia Pustaka Utama, 1998), 265).

126 Mark Ellingsen, The Evangelical Movement: Growth, Impact, Controversy, Dialog (Minneapolis: Augsburg Publishing House,1988), 46, 97-101.

127 Ibid., 135-195. 
(WEF) yang didirikan tahun 1951 dalam Konvensi Internasional Evangelikal di Wondschoten. Sejak tahun 2002, WEF berubah namanya manjadi World Evangelical Alliance atau disingkat WEA. Lembaga kerjasama lain yang bertaraf internasional di bidang penginjilan dunia adalah Lausanne Committee for World Evangelization yang berdiri tahun $1974 .{ }^{128}$

Menurut Ellingsen, pada dasarnya kaum Injili menganut paham yang sama dengan yang dianut oleh kaum Fundamentalis yang terkenal dengan sebutan five fundamentalism, yaitu: (1) inspirasi dan infallibilitas Alkitab; (2) Keilahian Kristus dan kelahiran-Nya dari perawan Maria; (3) penebusan yang bersifat menggantikan melalui kematian Kristus; (4) kebangkitan Kristus; (5) kedatangan-Nya yang kedua kali. Dengan keanekaragaman tradisi atau kelompok yang tergabung di dalamnya, maka ada pokok-pokok diyakini bersama oleh semua orang Injili, yaitu: (1) orientasi kritis terhadap Katolikisme Roma dan gerakan ekumenis; (2) teologi yang dijalankan dengan dialog harus didasarkan pada konsep inneransi Alkitab; (3) penekanan akan sangat pentingnya Alkitab bagi kehidupan Kristen; (4) prioritas dari berbagai dimensi pengalaman sebagai orang Kristen (pertobatan dan penyucian); (5) penekanan pada penginjilan dan karya misionari; (6) pemahaman akan etika Kristen berdasarkan hukum ketimbang situasi; (7) menolak persekutuan dengan orang-orang atau gereja-gereja yang tidak menerima berbagai komitmen di atas dan terbuka pada persekutuan dengan semua orang yang menerimanya, tanpa menghiraukan keberagaman doktrin dalam hal-hal lain. ${ }^{129}$

128 Ibid., 197; Sejarah PGLII. http://www.pglii.org/tentang/sejarah.htm. 129 Ellingsen, Op. Cit., 204. 


\section{Dialog Antarumat Beragama Menurut Kaum Injili}

\section{a. Pengertian Dialog Antarumat Beragama}

Secara umum, menurut kamus bahasa Indonesia dan bahasa Inggris, istilah dialog mengandung pengertian tindakan bercakap-cakap antara dua orang atau lebih yang dilakukan secara lisan maupun tulisan, secara langsung maupun tidak langsung, yang berfungsi untuk mengungkapkan isi pikiran dan perasaan, yang dilakukan secara jujur dalam pertukaran gagasan untuk memperoleh pemahaman bersama. ${ }^{130}$ Pengertian dialog dalam hubungan antarumat beragama tidaklah sederhana, malahan semakin rumit, karena dialog menjadi terkait dengan masalah keyakinan doktrinal dan teologis suatu agama. Karena itu, istilah dialog dalam hal ini menjadi tidak netral, yang makin jelas melalui istilah 'teologi dialog' dan 'dialog teologis'. Pemahaman doktrinal dan teologis seseorang atau suatu kelompok, khususnya menyangkut agama-agama lain akan mempengaruhi pendekatannya terhadap agama-agama lain dan secara otomatis juga mempengaruhi pemahamannya tentang dialog antarumat beragama.

Meski pemahaman tentang dialog antarumat beragama tidaklah sama untuk semua agama, namun sebagai perbandingan yang bertujuan untuk memperluas wawasan tentang dialog antarumat beragama, penulis mencoba menunjukkan beberapa definisi dialog antarumat beragama menurut teolog Protestan dan Katolik yang termasuk pada kelompok Oikumenis. Menurut Einar M. Sitompul (teolog Protestan), dialog antarumat beragama adalah pertemuan yang disengaja untuk bertukarpikiran, informasi dan pengalaman, tentang keyakinan masingmasing tanpa pretensi menganggap diri lebih benar. Dialog akan bermanfaat jika semua pihak yang terlibat bersedia untuk mendengar dan menghargai yang lain, sehingga terbuka kemungkinan untuk makin memahami keyakinan sendiri. ${ }^{131}$ E. Armada Riyanto, teolog

130 Dialog: 1. Percakapan (dalam sandiwara, cerita, dan sebagainya). 2. Karya tulis yang disajikan dalam bentuk percakapan antara dua tokoh atau lebih. ... Berdialog: bercakap-cakap, bersoal-jawab secara langsung (Departemen Pendidikan dan Kebudayaan, Kamus besar bahasa Indonesia (Jakarta: Balai Pustaka, 1996). 231). Dialogue: (Fr. dialogue; Gr. Dialogos, dialogu, dialegomai: to dispute; a conversation between two or more persons; a composition in which to or more persons are represented as conversing on some topic; a frank exchange of ideas or views on a spesific issue in an effort to attain mutual understanding (Harr E. Clarke, \& Lucinda R. Summers (eds.), The New Grolier Webster International Dictionary of the English Language (New York: Grolier Inc, 1976), 276. 2004), 5.

131 Einar M. Sitompul, Gereja Menyikapi Perubahan (Jakarta: BPK Gunung Mulia, 
Katolik, menyatakan bahwa pengertian dialog antarumat beragama (dalam bukunya ditulis 'dialog interreligius') telah dirumuskan secara tegas dalam dua dokumen Katolik, yakni Dialogue and Mission (DM, 1984) dan Dialogue and Proclamation (DP, 1991). Dalam DP9, pengertian dialog dibedakan menjadi tiga macam, yaitu: (1) dalam tingkat manusiawi seharihari, dialog sebagai komunikasi timbal balik yang bertujuan untuk bertukar informasi, untuk mendapatkan kesepakatan dan untuk menjalin persatuan; (2) dalam kaitan dengan tugas evangelisasi, dialog dipahami sebagai sikap hormat, penuh persahabatan, ramah, terbuka, suka mendengarkan orang lain; dalam pengertian khusus, dialog sebagai hubungan antarumat beragama yang positif dan konstruktif. Dialog yang dilangsungkan dalam hubungan dengan pribadi-pribadi dan jemaat-jemaat dari agama-agama lain, yang diarahkan untuk saling memahami dan saling memperkaya (DM3), dalam ketaatan kepada kebenaran dan hormat terhadap kebebasan. Juga termasuk di dalamnya kesaksian dan pendalaman keyakinan keagamaan masing-masing. ${ }^{132}$

\section{b. Pandangan Kaum Injili tentang “Dialog” Antarumat Beragama}

Pengertian dialog antarumat beragama di kalangan Injili tentulah didasari oleh pandangan mereka mengenai agama-agama lain. Secara historis-teologis, pemahaman dan pendekatan kaum Injili terhadap agama-agama lain dapat dilihat dari tiga dokumen utama mereka, yaitu: The Covenant Lausanne (1974), The Manila Manifesto (1989), dan The Iguassu Affirmation (1999). ${ }^{133}$

1) Dokumen "The Lausanne Covenant" (1974)

Dokumen The Lausanne Covenant dihasilkan dalam the International Congress on World Evangelization at Lausanne (atau biasa disebut Kongres Lausanne I) yang diadakan di kota Lausanne, Switzerland pada tanggal 16-25 Juli 1974. ${ }^{134}$ Kongres ini dihadiri oleh 2.700 peserta yang merupakan perwakilan gereja-gereja lebih dari 150 negara. The Lausanne

132 E. Armada Riyanto, Dialog interreligius: Historisitas, Tesis, Pergumulan, Wajah (Yogyakarta: Kanisius. 2010), 190-191.

$133 \mathrm{Di}$ antara kedua kongres besar itu, masih ada dokumen-dokumen kaum Injili yang dihasilkan dari enam konsultasi antara tahun 1977-1982, tetapi kesemuanya tidak membicarakan masalah agama-agama non Kristen dan keterlibatan kaum Injili dalam dialog antarumat beragama (Stott 1996, xvii-xx).

134 John Stott, The Lausanne Covenant: An Exposition and Commentary (Minneapolis, Minnesota: World Wide Publications, 1975), 3. 
Covenant terdiri dari 15 paragraf yang diawali dengan pendahuluan dan diakhiri dengan penutup. ${ }^{135}$

The Lausanne Covenant membicarakan hubungan orang Kristen dengan orang-orang non Kristen sebagai hal yang terkait dengan misi gereja untuk mengabarkan Injil. Di dalam pendahuluan Covenant ini disebutkan: “... We believe the Gospel is God's good news for the whole world, and we are determined by his grace to obey Christ's commission to proclaim it to all mankind and to make disciples of every nation", yang menurut John Stott, kalimat ini menyatakan bahwa tanggungjawab Kristen yang berhubungan dengan orang-orang non Kristen adalah melaksanakan misi pekabaran Injil (menjadi pelayan dan saksi Tuhan) dan melaksanakan tanggungjawab sosial. ${ }^{136}$

Pada paragraf 3 tentang "Keunikan dan Universalitas Kristus" tampak pemahaman kaum Injili mengenai agama-agama lain, yaitu bahwa para penganut agama-agama lain hanya memiliki pengetahuan tentang Allah melalui penyataan umum (melalui alam semesta dan hati mereka), tetapi pengetahuan itu tidak dapat menyelamatkan mereka sebab keselamatan hanya ada di dalam Yesus Kristus (pengetahuan khusus). Selanjutnya dikatakan bahwa kaum Injili menolak penghinaan terhadap Kristus dan Injil melalui segala macam sinkretisme dan dialog yang menyatakan bahwa Kristus berbicara melalui semua agama dan ideologi.

"We affirm that there is only one Saviour and only one gospel, although there is a wide diversity of evangelistic approaches.We recognise that everyone has some knowledge of God through his general revelation in nature. But we deny that this can save, for people suppress the truth by their unrighteousness. We also reject as derogatory to Christ and the gospel every kind of syncretism and dialogue which implies that Christ speaks through all religions and ideologies". ${ }^{137}$

Dari paragraf ini, jelas bahwa pada Kongres Lausanne I, sebenarnya yang mereka tolak adalah dialog kompromistik dengan menyatakan bahwa Kristus juga berbicara melalui semua agama dan ideologi. Stott sendiri menafsirkan teks ini dengan menyatakan bahwa Yesus

135 The Lausanne Covenant, http://www.lausanne.org/en/documents/lausannecovenant.html. (diakses 5 Oktober 2017).

136 Stott, Op. Cit., 7.

137 The Lausanne Covenant, Ibid. 
Kristus adalah juruselamat dunia, tetapi bukan berarti bahwa semua orang secara otomatis diselamatkan. Semua agama non Kristen tidak dapat menawarkan keselamatan yang ada di dalam Kristus. Keselamatan yang mereka ajarkan adalah keselamatan berdasarkan perbuatan baik manusia, bukan berdasarkan anugerah di dalam Yesus Kristus. ${ }^{138}$ Saphir Philip Athyal dalam tafsirannya terhadap paragraf ini menyatakan bahwa meskipun ada sejumlah bahaya dari sinkretisme, tetapi dialog tetaplah bermanfaat bagi Kekristenan. Menurut dia, setiap orang yang secara pribadi dan yang sungguh-sungguh setia kepada Kristus, "dialog” dengan umat dari agama-agama lain dapat menjadi suatu pengalaman yang memperkaya. Dengan kasih yang sungguh-sungguh, dia dapat berdialog dalam rasa hormat terhadap seseorang dan nilai-nilainya. Dengan segala kerendahan hati, dia bisa membagikan imannya. Dasar utama dari dialog religius adalah kesetaraan pribadi, bukan kesetaraan agama. Dialog akan sangat bernilai dalam bidang-bidang seperti: nilai-nilai rohani yang diterima bersama, hak asasi manusia dan kemerdekaan, perkembangan bangsa-bangsa, martabat para pekerja, moralmoral dasar, dsb. Selain itu, dialog juga bermanfaat dalam menjelaskan kesalahpahaman dan prasangka. Tetapi harus disadari pula bahwa dialog itu hanya bersifat superfisial. Memang ada banyak persamaan dalam pengalaman keagamaan, tetapi ada juga hal-hal yang berbeda, yang tidak bisa didialogkan. ${ }^{139}$

Pada paragraf 4 tentang "Sifat Penginjilan" dibicarakan tentang pentingnya kehadiran orangorang Kristen di dunia untuk mengabarkan Injil, yang memberitakan tentang karya penebusan Kristus, pengampunan dosa dan karunia Roh Kudus yang membebaskan. Dan untuk itu, kaum Injili juga membutuhkan dialog dengan orang-orang non Kristen, tetapi dengan tujuan untuk mendengarkan dengan kepekaan sehingga mereka dapat memahami orang-orang yang non Kristen. Di dalam paragraf itu disebutkan: "Our Christian presence in the world is indispensable to evangelism, and so is that kind of dialogue whose purpose is to listen sensitively in order to understand". Dalam tafsiran Stott dinyatakan bahwa kehadiran (presence) orang Kristen di dalam dunia tidak dapat menggantikan pemberitaan Injil, tetapi pemberitaan Injil ini sangat diperlukan, dan dalam situasi inilah dialog dengan orang-orang non Kristen adalah benar dan sangat diperlukan. Menurut Stott, dialog sering disalahgunakan. Sebagian orang Kristen menggunakannya untuk menggambarkan situasi kompromi di mana orang Kristen meninggalkan komitmennya sebagai orang Kristen dan menganggap Injil terbuka untuk diperdebatkan. Inilah jenis dialog yang ditolak kaum Injili dan dianggap

138 Stott, Op. Cit., 17.

139 Saphir Philip Athyal, “The Uniqueness and Universality of Christ dalam C. Rene Padila (ed.), The New Face of Evangelicalism: An International Symposium on the Lausanne Covenant (London: Hodder and Stoughton, 1979), 60-61. 
sebagai penghinaan terhadap Kristus dan Injil. Jadi dialog menurut Stott adalah percakapan di mana kedua kelompok (pen. maksudnya Kristen dan non Kristen) bersikap serius dan masing-masing siap untuk mendengar kepada yang lain. Tujuannya adalah mendengar dengan kepekaan untuk memahami. Mendengar yang demikian adalah penting sebagai pendahuluan untuk penginjilan, dengan demikian Kabar Baik dapat dibagikan berdasarkan pemahaman akan posisi dan masalah-masalah orang lain. ${ }^{140}$

Dari isi The Lausanne Covenant ini jelaslah pandangan kaum Injili terhadap agama-agama lain, yaitu bahwa agama-agama lain memiliki pengetahuan akan Allah yang tidak lengkap, karena hanya memiliki penyataan umum, tetapi tidak memiliki penyataan khusus. Agamaagama lain tidak dapat menawarkan keselamatan yang sesungguhnya, malahan mereka sendiri perlu diselamatkan melalui pemberitaan Injil, dan kaum Injili meyakini panggilan mereka untuk hadir di dalam dunia sebagai pekabar Injil. Pemahaman ini menjadi dasar bagi dialog kaum Injili. Bagi mereka, dialog adalah alat untuk mengabarkan Injil kepada para penganut agama-agama lain.

2) Dokumen Kongres Lausanne II / Manila Manifesto (1989)

Kongres Lausanne II yang merupakan kongres internasional tentang penginjilan dunia diadakan diadakan di Manila tanggal 10-22 Juli 1989. Kongres ini dihadiri oleh 3.586 peserta yang mewakili 186 negara dan banyak denominasi dan organisasi parachurch. Tujuan implisit dari kongres ini adalah untuk mengumpulkan orang-orang Kristen yang beranekaragam untuk bertemu, berdoa, studi, berdiskusi, dan meneguhkan alasan bersama untuk penginjilan dunia. Isi dari Kongres Lausanne II adalah perluasan dari Kongres Lausanne I yang diteguhkan kembali dengan "Manila Manifesto". ${ }^{141}$

Manila Manifesto terdiri dari 21 butir prinsip kaum Injili di mana pada butir ke-7, ke-18 dan ke-20 tampak sikap dan pandangan mereka terhadap agama-agama lain. Pada butir ke-7 dinyatakan bahwa agama dan ideologi lain bukanlah jalan alternatif menuju Allah karena Kristus adalah satu-satunya jalan. Pada butir ke-18, dinyatakan bahwa kaum Injili wajib mempelajari masyarakat di mana mereka tinggal dengan tujuan untuk memahami struktur, nilai, dan kebutuhannya, dan dengan begitu, dikembangkan suatu strategi misi yang tepat. Selain itu pada butir ke-20 diteguhkan bahwa kaum Injili menunjukkan solidaritas mereka dengan orang-orang yang menderita karena Injil dan akan berusaha untuk mempersiapkan

140 Stott, Op. Cit., 22-23.

141 David S. Dockery (ed.), Southern Baptists \& American Evangelicals: The Conversation Continues (Nashville: Tennessee: Broadman \& Holman Publishers, 1993), 195. 
diri untuk kemungkinan yang sama, dan mereka akan bekerja untuk mendapatkan kebebasan beragama dan kebebasan politik di segala tempat.

"7. We affirm that other religions and ideologies are not alternative paths to God, and that human spirituality, if unredeemed by Christ, leads not to God but to judgment, for Christ is the only way.; 18. We affirm our duty to study the society in which we live, in order to understand its structures, values and needs, and so develop an appropriate strategy of mission.; 20. We affirm our solidarity with those who suffer for the gospel, and will seek to prepare ourselves for the same possibility. We will also work for religious and political freedom everywhere" ${ }^{, 142}$

Rumusan pernyataan Kongres Lausanne II terdiri dari 12 paragraf, adalah perluasan dari isi Kongres Lausanne I. Di dalam paragraf 1, 3, 12, tampak perhatian kaum Injili terhadap agama-agama lain. Paragraf 1 memperlihatkan pengakuan kaum Injili bahwa betapapun manusia telah jatuh dalam dosa, namun mereka memiliki martabat yang melekat pada dirinya sebagai gambar Allah. Kaum Injili mengakui bahwa masih ada hal-hal yang baik dalam diri manusia sebagai gambar Allah yang telah rusak itu, yaitu mereka masih mampu memiliki hubungan-hubungan yang mengasihi, melakukan perbuatan-perbuatan baik, dan menghasilkan karya seni yang indah, namun sebaik apapun mereka, itu sudah cacat dan tidak sesuai di hadapan Tuhan. Karena itu, dengan cara apapun manusia tidak bisa menyelamatkan dirinya.

“... Although God's image in human beings has been corrupted, they are still capable of loving relationships, noble deeds and beautiful art. Yet even the finest human achievement is fatally flawed and cannot possibly fit anybody to enter God's presence. Men and women are also spiritual beings, but spiritual practice and self-help techniques can at the most alleviate felt needs; they cannot address the solemn realities of sin, guilt and judgment. Neither human religion, nor human righteousness, nor sociopolitical programs can save people. Self-salvation of every kind is

142 Manila Manifesto, http://www.lausanne.org/en/documents/manilamanifesto.html. 
impossible. Left to themselves, human beings are lost forever. ...". ${ }^{43}$

Paragraf 3 Lausanne II menunjukkan bahwa kaum Injili menyadari pentingnya kehadiran mereka di dunia pluralistik untuk mengabarkan Injil dengan sikap berani, sama seperti pada abad pertama, di mana ada "banyak allah dan tuhan". Mereka juga mengakui bahwa kadangkadang ada unsur-unsur kebenaran dan keindahan dalam agama-agama lain karena manusia yang ada di dalamnya diciptakan segambar dengan Allah. Meski demikian, agama-agama lain bukanlah injil-injil alternatif dan keselamatan tidak dapat ditemukan di dalam mereka dan terlepas dari karya-Nya melalui iman. Kaum Injili juga menyesalkan sikap dan praktik yang salah pada pekabaran Injil di masa lampu yang dilakukan dalam kebodohan, kesombongan, tidak menghormati, dan bahkan dalam permusuhan. Tetapi kaum Injili meyakini bahwa mereka sudah ditentukan untuk membawa kesaksian yang positif dan tidak berkompromi mengenai keunikan Tuhan Yesus, yang telah hidup sebagai manusia, mati dan bangkit, dalam semua aspek pekerjaan penginjilan termasuk dalam dialog antarumat beragama. Ini artinya, keunikan Yesus Kristus harus diberitakan melalui dialog antarumat beragama.

"We are called to proclaim Christ in an increasingly pluralistic world. There is a resurgence of old faiths and a rise of new ones. In the first century too there were "many gods and many lords". Yet the apostles boldly affirmed the uniqueness, indispensability and centrality of Christ. We must do the same.

Because men and women are made in God's image and see in the creation traces of its Creator, the religions which have arisen do sometimes contain elements of truth and beauty. They are not, however, alternative gospels. Because human beings are sinful, and because "the whole world is under the control of the evil one", even religious people are in need of Christ's redemption. We, therefore, have no warrant for saying that salvation can be found outside Christ or apart from an explicit acceptance of his work through faith. ... We therefore, reject both the relativism which regards all religions and spiritualities as equally valid approaches to God, and the syncretism which tries to mix faith in Christ with other faiths.... 
In the past we have sometimes been guilty of adopting towards adherents of other faiths attitudes of ignorance, arrogance, disrespect and even hostility. We repent of this. We nevertheless are determined to bear a positive and uncompromising witness to the uniqueness of our Lord, in his life, death and resurrection, in all aspects of our evangelistic work including inter-faith dialogue". ${ }^{44}$

Paragraf 12 menyatakan bahwa kaum Injili sudah mengubah metode-metode penginjilan yang tidak layak digunakan, dan memberi kebebasan kepada pendengar Injil untuk mempertimbangkannya sendiri. Kaum Injili juga menolak pendekatan apapun yang berusaha untuk memaksa orang-orang lain bertobat. Selain itu, kaum Injili menghendaki kebebasan beragama bagi semua orang, bukan hanya bagi orang Kristen, yaitu kebebasan dalam hal mengakui, mempraktikkan dan mempropagandakan agama mereka.

“... Secondly, Christians renounce unworthy methods of evangelism. Though the nature of our faith requires us to share the gospel with others, our practice is to make an open and honest statement of it, which leaves the hearers entirely free to make up their own minds about it. We wish to be sensitive to those of other faiths, and we reject any approach that seeks to force conversion on them.

Thirdly, Christians earnestly desire freedom of religion for all people, not just freedom for Christianity. In predominantly Christian countries, Christians are at the forefront of those who demand freedom for religious minorities. In predominantly nonChristian countries, therefore, Christians are asking for themselves no more than they demand for others in similar circumstances. The freedom to "profess, practice and propagate" religion, as defined in the Universal Declaration of Human Rights, could and should surely be a reciprocally granted right....". ${ }^{145}$

Bila dibandingkan antara hasil Kongres Lausanne I dan Kongres Lausanne II, tampaknya tidak ada perubahan pemahaman kaum Injili tentang agama-agama non Kristen dan tentang pentingnya dialog antarumat beragama. Menurut mereka, agama-agama lain tetaplah cacat 
dan tidak layak di hadapan Allah; mereka adalah gambar Allah yang sudah rusak dan dikuasai dosa; dan agama-agama itu tidak bisa menyelamatkan manusia. Karena itu, dialog dirasakan sangat perlu untuk menjadi jalan masuk atau sarana persiapan bagi penyampaian Injil atau keselamatan di dalam Yesus Kristus. Tetapi tampak pula perkembangan dalam Kongres Lausanne II setidaknya dalam empat hal, yakni: (1) ada pengakuan akan nilai-nilai positif dalam agama-agama lain karena mereka juga diciptakan segambar dengan Allah (2) adanya pengakuan bersalah atau penyesalan tentang sikap dan praktik penginjilan di masa lalu yang dilakukan dengan kebodohan, kesombongan, tidak mengormati dan permusuhan (3) ada keterbukaan dalam perubahan metode penyampaian Injil yang menolak pemaksaan keyakinan Kristen terhadap agama-agama lain; (4) ada keterbukaan untuk bekerjasama dalam urusan-urusan memperjuangkan kebebasan beragama bagi agama apapun, yang sebelumnya tidak dibicarakan dalam Kongres Lausanne I.

\section{3) Iguassu Affirmations (1999)}

Setelah Lausanne II, konsensus yang sudah dihasilkan oleh kaum Injili menyangkut pluralisme agama di mana itu menunjukkan keterbukaan dan keterlibatan kaum Injili dalam dialog antarumat beragama. Pada tanggal 10-15 Oktober 1999 the World Evangelical Fellowship Missions Commission (WEF) telah mengadakan pertemuan di Foz de Iguassu, Brazil yang dihadiri oleh 160 praktisi misi, para ahli misi dan para pemimpin gereja yang berasal dari 53 negara. Pertemuan ini diadakan dengan tiga tujuan, yakni: (1) melakukan refleksi bersama mengenai berbagai tantangan dan kesempatan yang dihadapi misi sedunia untuk menyambut milenium baru; (2) meninjau berbagai aliran misiologi dan praktik Injili abad kedua puluh, khususnya sejak Kongres Lausanne 1974; melanjutkan pengembangan dan penerapan misiologi alkitabiah yang relevan yang merefleksikan keberagaman budaya dari umat Allah. Rumusan yang dihasilkan dalam pertemuan ini terdiri dari: Pembukaan, sembilan paragraf pernyataan deklaratif, empat belas paragraf pernyataan komitmen, dan pernyataan janji. ${ }^{146}$

Dalam pembukaan Afirmasi Iguassu tampak perhatian yang semakin besar terhadap pluralisme agama dan itu dipandang sebagai tantangan terhadap kebenaran Injil. Untuk itu, kemunculan dari berbagai gerakan misi disambut dengan sukacita, namun teori dan praktik only/13.0.html?start=5. November (Web-only) 1999, Vol. 43. 
dari berbagai gerakan misi itu tidak semuanya diambil oleh kaum Injili. Mereka masih menerapkan paradigma lama.

"The diverse religious aspirations of people, expressed in multiple religions and spiritual experimentation, challenge the ultimate truth of the Gospel. ... We rejoice in diverse missiological voices emerging around the world, but we confess that we have not taken them all into our theory and practice. Old paradigms still prevail. Participation by and awareness of the global church, as well as mission from people of all nations to people of all nations, are needed for a valid missiology in our time."

Di dalam pernyataan komitmen paragraf ke-5 ditegaskan kembali mengenai keteguhan mereka pada keunikan Yesus Kristus sebagai Juruselamat di tengah-tengah pluralisme agama. Toleransi dan pemahaman yang makin meningkat mengenai agama-agama lain, tidak harus membuat mereka menyelaraskan diri dengan kepercayaan lain, tetapi mereka akan tetap berkomitmen untuk menjadi agen-agen rekonsiliasi di tengah-tengah permusuhan antar agama dan tetap memberitakan Injil Yesus Kristus dengan setia dan dengan kasih yang penuh kerendahan hati.

"Religious pluralism challenges us to hold firmly to the uniqueness of Jesus Christ as Savior even as we work for increased tolerance and understanding among religious communities. We can not seek harmony by relativizing the truth claims of religions. Urbanization and radical political change have bred increased interreligious and ethnic violence and hostility. We commit ourselves to be agents of reconciliation. We also commit ourselves to proclaim the Gospel of Jesus Christ in faithfulness and loving humility."

Tampak jelas bahwa konsep mereka mengenai dialog antarumat beragama tetap konsisten, yaitu bahwa dialog adalah alat yang digunakan untuk memberitakan Injil. 
2. Metode-metode Dialog Antar Umat Beragama

Untuk terlibat dalam dialog yang bermakna, ada banyak usulan yang diberikan baik oleh kalangan Protestan oikumenis, Katolik, maupun oleh kalangan Injili sendiri. Pandangan oikumenis tentang dialog antarumat beragama sudah dirumuskan dalam "Guidelines on Dialogue" sebagai pedoman bagi WCC. Menurut pedoman ini, orang Kristen dapat melakukan dialog komunitas, yaitu suatu dialog yang didorong oleh adanya kesadaran bahwa umat Kristen hadir sebagai sesama bagi orang-orang yang berbeda agama, baik di kota-kota maupun di desa-desa. Untuk itu, perlu menjalin hubungan-hubungan yang mengungkapkan kepedulian dan yang mencari pemahaman bersama tentang banyak hal yang bersifat praktis, misalnya menyangkut masalah-masalah kehidupan modern: sosial, politik, ekologi, dan berbagai hal yang bersifat umum. Dialog-dialog bisa melampaui lokal sehingga sampai pada tingkat nasional dan internasional dalam rangka ikut mewujudkan perdamaian dan keadilan di dunia. Alasan lain, sesungguhnya dialog harus dikembangkan sebagai gaya hidup yang menekankan perjumpaan dan keterbukaan yang mendalam sebagai bagian dari perintah Allah dalam Hukum Taurat maupun dalam Hukum Kasih. ${ }^{147}$

Pandangan E. Armada Riyanto dikemukakan dalam konteks keyakinan Katolik, menekankan bahwa ada empat jenis dialog yang bisa dilakukan dan sebenarnya semua jenis itu bisa dilakukan oleh siapapun, namun harus tetap mempertimbangkan subjeknya karena objek atau tema dialog yang berbeda bobotnya. Keempat jenis dialog yang dimaksud adalah cara atau model pengungkapan dialog, yakni:

a. Dialog kehidupan. Dialog ini bisa dilakukan oleh semua orang Kristen karena hal itu menyangkut ciri kehidupan pengikut Kristus yang harus mengungkapkan nilai-nilai Injil dalam segala bidang kehidupan sehari-hari.

b. Dialog Karya. Dialog ini dapat dilakukan oleh semua orang Kristen bersama-sama dengan para penganut agama lain dalam bentuk karya-karya yang membangun dan meningkatkan martabat manusia, serta menghadapi masalah-masalah dunia secara bersama-sama.

c. Dialog Teologis. Dialog ini berkaitan dengan menyangkut soal-soal teologis yang sering rumit, yang bertujuan untuk menggumuli, memperdalam, dan memperkaya warisanwarisan keagamaan masing-masing, serta mengajak untuk menerapkan pandanganpandangan teologis dalam menyikapi persoalan-persoalan yang dihadapi umat manusia pada umumnya. Dialog semacam ini tidak boleh bersifat menyerang dan menuntut.

147 World Council of Churches, Op. Cit., 9-12. 
d. Dialog Pengalaman Keagamaan. Ini adalah dialog tingkat tinggi karena dilakukan oleh orang-orang yang tetap berakar pada tradisi keagamaan masing-masing pribadi, namun mereka berbagi pengalaman doa, kontemplasi, meditasi, bahkan pengalaman iman dalam arti yang lebih mendalam (pengalaman mistik). Karena itu, dialog ini sangat mengandalkan iman yang mantap dan mendalam. ${ }^{148}$

Apa yang diungkapkan oleh Riyanto sebagai dialog kehidupan dan dialog karya sebenarnya sama dengan yang diungkapkan oleh Hesselgrave sebagaimana yang dikutip oleh Netland, bahwa kaum Injili tetap bisa berpartisipasi dalam dialog dengan para penganut agama-agama lain dengan terlibat dalam dialog antarumat beragama yang memajukan kebebasan beragama untuk semua agama, yaitu untuk beribadah dan bersaksi; terlibat dalam dialog antarumat beragama yang berusaha memenuhi kebutuhan jasmani dan kebutuhan sosial umat manusia, yang juga mencakup dialog yang memperhatikan ancaman-ancaman yang dihadapi bersama seperti: pengembangan nuklir, kerusakan lingkungan, bencana kelaparan, bencana alam, dsb.; dan terlibat dalam dialog yang bertujuan untuk menghancurkan prasangka, kecurigaan, dan kebencian di dalam dunia umat beragama karena tidak ada agama yang bebas dari kefanatikan atau sikap keras dalam memegang pendirian. ${ }^{149}$

\section{Metode Dialog "Passing Over"}

Di tengah-tengah pergumulan orang Kristen dalam menghadapi pluralitas agama pada masa kini, di satu pihak menuntut komitmen yang sungguh-sungguh pada imannya sendiri dan di lain pihak, menuntut tanggungjawabnya untuk memahami agama-agama lain. Sementara itu, ketiga pendekatan terhadap agama-agama lain yang disediakan melalui pendekatan eksklusivisme, inklusivisme dan pluralisme tidak bisa memberi jalan keluar bagi pergumulan tersebut. Untuk mengatasi kesulitan tersebut, muncullah teologi komparatif. Menurut Y.B. Prasetyantha, teologi komparatif adalah suatu upaya untuk memikirkan kembali Kekristenan dalam relasinya dengan agama-agama lain secara komparatif, yakni dengan mempelajari ajaran dan praksis agama-agama lain secara serius. Dalam berteologi secara komparatif, seorang teolog Kristen selalu tertantang untuk setia pada kebenaran Kristen dan selalu rindu membantu orang-orang yang seiman dengannya dalam memahami dan menghayati iman

148 E. Armada Riyanto, Dialog Agama dalam Pandangan Gereja Katolik (Yogyakarta: Kanisius. 1995), 110-113.

149 Harold A. Netland, Dissonant Voices: Religious Pluralism and the Question of Truth (USA: Wm. B. Eerdmans Publishing Co., 1991), 299-300. 
mereka secara lebih penuh dalam konteks pluralitas iman. Dia juga selalu berusaha terbuka untuk mempelajari keyakinan orang-orang yang beragama lain. ${ }^{150}$

Y.B. Prasetyantha menyatakan bahwa teologi komparatif adalah usaha untuk memahami arti, makna dan sumbangan iman kristiani dalam konteks keberagaman iman dengan menelitinya secara seksama dalam "terang" ajaran-ajaran tradisi religius yang lain. Berteologi dalam konteks perbandingan berarti orang-orang kristiani menganggap kebenarankebenaran sebagaimana diyakini oleh penganut agama lain sebagai sumber untuk memahami iman kristiani mereka sendiri. Jelaslah bahwa tujuan teologi komparatif adalah membantu orang-orang kristiani untuk sampai pada pengertian yang lebih mendalam tentang tradisi iman mereka. Dalam konteks tugas teologi: fides quaerens intellectum, berteologi secara komparatif berarti berusaha untuk membangun korelasi-korelasi kritis yang saling menguntungkan antara interpretasi tentang tradisi religius yang khusus dan interpretasi terhadap situasi kontemporer. Teologi komparatif mencoba untuk sampai pada kebenaran kristiani dengan menggunakan sumber dan acuan teologis yang semakin luas, termasuk unsur-unsur non kristiani, tetapi tanpa mengklaim diri mengetahui lebih banyak tentang penganut-penganut agama lain daripada para penganut agama itu mengenal diri mereka sendiri"151.

Teologi komparatif dikenal juga dengan sebutan teologi "melintasi batas agama" atau "passing over" yang dimulai dengan berangkat dari agama semula, memasuki daerah agama lain, dan harus kembali kepada agama semula. ${ }^{152}$ Secara historis, istilah teologi komparatif (comparative theology) sudah digunakan sejak abad ke-19 dan sudah dipraktikkan oleh orang-orang dari kalangan agama lain, misalnya di kalangan Hindu (misalnya: Sri Ramakhrisna dan Swami Vivekananda), Buddha (misalnya: D.T. Suzuki), Islam (para sufi) dan Katolik (misalnya: Thomas Merton, Roberto de Nobili, dll.). Menurut Prasetyantha, teologi komparatif masih relatif baru dan belum matang sehingga para teolog komparatif masih mencari cara bagaimana menjalankannya dengan benar, dan di antara mereka belum ada kesepakatan mengenai metodenya. Tetapi ada sejumlah metode yang sudah dikembangkan oleh John Renard, yaitu: perkembangan inter dan intra (pembentukan dan pendefinisian komunitas iman); Inkulturasi dan konflik; inter-tekstual (cara membaca teks

150 Y.B. Prasetyantha. “Teologi Komparatif: Pendekatan Baru Terhadap Pluralitas Iman" dalam jurnal Diskursus Vol. 6, No. 2, Oktober 2007. 195-210. http://isjd.pdii.lipi.go.id/admin/jurnal/6207195210.pdf.

151 lbid.

152 Noer, Op. Cit., 281. 
komunitas lain); pertukaran literatur dan artistik; fenomenologis atau tematis (penjelasan iman sendiri dengan melihat paralelnya pada komunitas lain); hermeneutik inter-tekstual (membaca teks komunitas lain tanpa berpolemik); perbandingan dalam metodologi dan struktur. Dari semua model tersebut, dituntut suatu pemahaman yang mendalam mengenai tradisi iman sendiri dan tradisi iman lain. Noer juga menyatakan bahwa dalam melakukan teologi komparatif, perasaan takut harus dihilangkan, dan harus mempersiapkan pengetahuan yang mendalam tentang agamanya sendiri dan pengetahuan tentang agama-agama lain. Menurut dia, yang lebih penting adalah dia berangkat dari agamanya sendiri, dan setelah mengembara ke dalam agama-agama lain, dia harus kembali dengan wawasan baru kepada agamanya. $^{153}$

\section{Analisis Teologis-Pedagogis}

Secara historis-teologis, pemahaman kaum Injili sejak Kongres Lausanne I, Kongres Lausanne II dan Pertemuan di Iguassu menunjukkan sikap yang konsisten, bahwa dialog sangat diperlukan, tetapi dalam rangka menyampaikan kebenaran Injil. Pemahaman tentang agama-agama lain telah mengalami perkembangan, yaitu dari pemahaman yang bernada menghakimi bahwa para penganut agama lain tidak punya pengetahuan lengkap dan tidak ada keselamatan di dalam mereka (Lausanne I), telah berkembang pemahaman yang lebih bersifat positif, yakni dengan mengakui adanya kebaikan dan keindahan di dalam agama-agama lain, serta adanya pengakuan bahwa para penganut agama lain juga adalah gambar Allah, namun yang telah jatuh ke dalam dosa, sehingga perlu ditebus dan diselamatkan.

Pemahaman dan sikap yang demikian adalah tetap menunjukkan sikap keberagamaan yang eksklusif, namun yang juga menyadari pentingnya kehadiran mereka di tengah-tengah para penganut agama lain dalam rangka berdialog, yang menurut keyakinan iman mereka itu adalah sarana untuk menyampaikan kebenaran dan berita keselamatan di dalam Yesus Kristus. Pemahaman dan keyakinan yang demikian, menurut penulis, adalah hal yang positif, yang tentu juga ada di dalam hati para penganut agama lain ketika berdialog. Menurut penulis, menjadi seorang yang eksklusif dalam keyakinan dan tetap terbuka dalam dialog antarumat beragama adalah tetap bisa dimungkinkan. Keyakinan seseorang tidak harus dikorbankan demi kepentingan dialog. Menjaga konsistensi dan komitmen terhadap keyakinan alkitabiah adalah suatu keharusan bagi seorang Injili. Dengan demikian, apa yang 
dirumuskan sebagai suatu keyakinan yang teguh dalam Kongres Lausanne I dan II, serta dalam pertemuan Afirmasi Iguassu, adalah menunjukkan jati diri kaum Injili yang memegang teguh keyakinannya pada kebenaran Alkitab, dan itu tidak harus berarti sebagai suatu kesombongan atau sikap superior. Meski demikian, keyakinan yang kokoh pada suatu ajaran, semestinya tidak menghalangi perjumpaan dan komunikasinya dengan penganut agamaagama lain.

J. Hesselgrave juga menegaskan perlunya dialog antarumat beragama dengan mengutip ayat-ayat Alkitab yang memperlihatkan bahwa Yesus dan Paulus juga terlibat dalam dialog, termasuk dengan para penganut agama-agama lain, dan itu dilakukan mereka dengan begitu bebas, bukan untuk menemukan kebenaran, melainkan untuk menyampaikan kebenaran. Tetapi Hesselgrave juga melihat adanya masalah yang menyebabkan ketidakterlibatan kaum Injili dalam dialog antarumat beragama secara bermakna dan produktif, yaitu: karena terbatasnya pemahaman mereka tentang agama-agama lain dan adanya kebingungan menyangkut sifat dan sasaran-sasaran dialog sebagai alat mengkomunikasikan iman Kristen. ${ }^{154}$

Dialog yang menggunakan metode "lintas batas (passing over)" adalah salah satu metode yang bisa digunakan kaum Injili dalam melakukan dialog antar umat beragama. Untuk sampai pada tingkatan dialog yang seperti ini, tentu kaum Injili akan mengalami kesulitan dan pergumulan yang berat, dan bukan hanya kalangan Injili, tetapi kebanyakan orang dari agama apapun pasti mengalami hal yang sulit untuk melakukannya. Ini adalah suatu kegiatan yang perlu keberanian, daya adaptasi yang sangat kuat, kesiapan mental dan spiritual yang sangat besar karena tidak mudah orang untuk keluar dari dunia agamanya dan memasuki dunia agama-agama lain secara sepenuhnya, tetapi dengan tetap pada keyakinan utamanya. Bukan itu saja, orang yang ingin mempraktikkan teologi ini harus memiliki kemampuan intelektual yang tinggi dan kekuatan batiniah yang luar biasa. Kekuatan batiniah yang dimaksud adalah sikap yang rendah hati, yang bersedia untuk mengosongkan diri (kenosis) untuk suatu waktu untuk tujuan mengenal dan memahami orang-orang lain yang berbeda keyakinan, sampai saatnya dia harus kembali kepada basisnya yang semula. Tindakan mengosongkan diri ini memerlukan kerendahan hati yang luar biasa, karena dia bersedia untuk sementara seakan-akan melepaskan jati dirinya untuk masuk ke dalam jati diri orang

154 David J. Hesselgrave, "Traditional Religions, New Religions, and the Communication of the Christian Faith" dalam Irving Hexham, Stephen Rost, John Morehead, John W. Morehead II (eds.), Encountering New Religious Movements: A Holistic Evangelical Approach (Grand Rapids, Michigan: Kregel Publication Inc., 2004), 152-154. 
lain; untuk keluar dari dunianya, dari cara-cara dan kebiasaannya untuk masuk ke dalam dunia, cara-cara dan kebiasaan orang lain.

Kenosis (Yun.) artinya adalah 'pengosongan diri' dan digunakan oleh Paulus dalam Filipi. 2:7 yang mengacu pada penolakan Yesus untuk tinggal dalam keadaan kemuliaan bersama sang Bapa dan memilih hidup dan mati bersama dengan manusia. ${ }^{155}$

H.R Mackintosh berpendapat bahwa sebagai kata benda, kenosis dipakai dalam arti teknis, tentang teori Kristologis yang menunjukkan bagaimana Oknum kedua dalam Trinitas dapat memasuki kehidupan manusia, sehingga memungkinkan adanya pengalaman manusia sejati yang diuraikan oleh para penginjil. Teori kenosis ini dikemukakan pada pertengahan abad ke-19 oleh Thomasius dari Erlangen, Jerman, dan intisari pandangan kenotik ini dinyatakan dengan jelas oleh J.M Creed, bahwa Logos ilahi oleh Inkarnasi-Nya telah melepaskan sifat keilahian-Nya, yaitu kemahatahuan dan kemahakuasaan, sehingga dalam hidup-Nya di dunia ini Oknum Ilahi semata-mata dinampakkan hanya melalui kesadaran seorang manusia' ${ }^{156}$.

Kaum Injili meyakini bahwa dialog adalah alat untuk menyampaikan kebenaran dan mengharapkan bahwa melaluinya orang mengalami "pertobatan" sesuai dengan yang diyakini kaum Injili. Akan tetapi, dialog juga harus mempertimbangkan hati nurani orang lain, yaitu dalam dialog orang harus merasakan kemerdekaan dan tidak merasa diintimidasi karena ada maksud-maksud terselubung untuk memindahkan orang lain ke dalam lingkungan agamanya. Untuk itu, dalam dialog, kaum Injili harus benar-benar melakukannya dalam kerendahan hati. Kaum Injili dapat mendengarkan pendapat orang lain tentang manfaat dan metode dialog antarumat beragama. Kaum Injili bebas untuk mempertimbangkan dan mengambil apa yang perlu dan bisa diterapkan sesuai dengan keyakinan Injili tanpa ada ketakutan atau kekuatiran, tanpa keterpaksaan dan kemarahan pada pihak lain, karena dialog harus dilakukan dengan bebas, sukarela dan sukacita, meskipun ada pihak lain yang mungkin merasa tidak puas akan keyakinan kaum Injili dalam melaksanakan dialognya.

Penerapan metode dialog yang di atas mungkin belum menyentuh sampai mendalam pada hal-hal yang bersifat teologis karena terbatasnya pengenalan akan agama-agama lain. Secara 
teoritis, pengenalan akan agama-agama lain bisa dilakukan, tetapi tidak sejelas bila bersentuhan langsung dengan dunia mereka yang sesungguhnya. Model dialog yang keempat yang diutarakan oleh Riyanto, yakni dialog pengalaman keagamaan atau dialog yang dilakukan melalui pendekatan teologi komparatif (biasa juga disebut "melintas batas" atau "passing over") akan memampukan setiap orang mengalami pengenalan yang mendalam mengenai para penganut agama lain. Menurut penulis, pendekatan ini tidak bertentangan dengan iman Kristen, karena dalam pendekatan ini orang tidak pindah agama atau keyakinan, juga bukan sedang dalam pencarian jati diri dan bukan sedang mencoba-coba mencicipi rasa keagamaan yang lain. Justru orang yang melakukannya adalah orang yang berkeyakinan kokoh, yang sedang dalam penelitian dan pembelajaran yang serius tentang agama-agama lain. Dia melakukan dialog ini untuk memiliki pemahaman yang lebih dalam lagi tentang keyakinan orang-orang dalam agama lain, dan dengan itu justru akan memperkuat keyakinannya sendiri. Hasil dari dialog itu akan mempertajam dan memperkuat pelayanannya setelah kembali dari perjalanan pengembaraannya menuju tempatnya yang semula.

Jika melihat rumusan Kongres Lausanne I, Kongres Lausanne II serta Afirmasi Iguassu, yang sudah menjadi konfesi bersama seluruh kaum Injili di dunia, tampaknya sangat sulit bagi kaum Injili untuk mau terbuka kepada pendekatan teologi komparatif ini. Sekali lagi, hal ini juga sulit dilakukan oleh para penganut agama lain secara kelembagaan, hanya sedikit orang yang berani melakukannya berdasarkan keputusan secara personal. Dan mengingat bobot dialog menuntut keahlian yang sangat tinggi secara intelektualitas, mentalitas dan spiritualitas, maka tentu dialog seperti ini tidak perlu dilakukan oleh semua orang. Hanya akan bermanfaat bila dilakukan oleh para teolog yang menyadari fungsi dan manfaatnya bagi dirinya dan bagi banyak orang. Para pemikir teologi agama-agama melihat ada hal-hal positif yang dibawa oleh orang-orang yang pulang dari pengembaraannya ini, yaitu ketika mereka melintasi agama-agama lain dan kembali kepada agamanya yang semula, mereka membawa wawasan baru yang memperdalam keyakinan imannya yang semula dan makin memperdalam pemahaman dan keterbukaannya pada penganut agama-agama lain. Mungkin di kemudian hari akan ada teolog-teolog Injili yang berani menjalankan pendekatan ini, dan memberi dampak positif yang luar biasa bagi keterlibatan kaum Injili dalam dialog antarumat beragama yang lebih bermakna.

Secara pedagogis, pendidikan agama Kristen harus membuka ruang dialog dengan pihak agama-agama lain. Para naradidik harus dididik untuk memiliki sikap yang terbuka kepada keberagaman agama, dan mampu mengelola percakapan-percakapan yang kreatif, 
positif, dan membangun di antara orang-orang yang berlainan agama atau kepercayaan. Pendidikan agama Kristen harus mampu membentuk pribadi-pribadi yang bisa menerima, menghargai, dan mendukung para penganut lain dengan ketulusan. Hal ini juga dikemukakan oleh Gabriel Moran, sebagaimana dikutip oleh Hope S. Antone, bahwa pendidikan agama digambarkan sebagai suatu percakapan mengenai agama-agama yang lebih luas dan lebih inklusif di tingkat antarnegara, antaragama, antargenerasi dan antarlembaga. Pendidikan agama tidak dibatasi hanya pada gereja sendiri. ${ }^{157}$

Antone juga mengutip pemikiran Norma H. Thompson mengenai dalam muatan pendidikan, tiga komponen, yakni kognitif, afektif, dan tingkah laku, penting untuk terus dipertimbangkan. Para naradidik harus memiliki pengetahuan yang cukup akan fakta-fakta mengenai agama-agama. Pengetahuan itu akan membuang ketakutan, kecurigaan, prasangka, dan kebencian. Komponen afektif juga akan membangkitkan kesadaran akan adanya hubungan historis agama dengan ungkapan kultural dan artistik yang memunculkan perasaan kekaaguman, keindahan, rasa hormat. Selanjutnya semuanya itu akan membentuk tingkah laku yang saling menghargai, menghormati, kerjasama, persahabatan, keadilan, perdamaian, dan inklusivitas terhadap para penganut agama yang berbeda. ${ }^{158}$

Berdasarkan uraian di atas, maka pendidikan agama Kristen perlu selalu mengembangkan dialog yang bermakna dalam rangka menjalin hubungan yang positif dengan para penganut agama lain. Model dialog yang tepat perlu untuk selalu mempertimbangkan konteks yang sedang berlangsung.

\section{B. Kesimpulan dan Saran}

Ada beberapa kesimpulan yang dapat diberikan dalam makalah ini, yaitu:

1. Kaum Injili adalah salah satu aliran dalam Kekristenan yang muncul sebagai reaksi yang keras terhadap sikap kalangan Fundamentalis pada tahun 1940-an. Gerakan ini muncul sebagai akibat perpecahan dalam tubuh gerakan Fundamentalisme Amerika yang bersifat radikal dan separatis dalam perlawanannya terhadap teologi liberal dan bentuk-bentuk pemikiran Pencerahan. Kaum Injili sendiri lebih memilih untuk memasuki dunia sekuler,

157 Hope S. Antone, Pendidikan Kristiani Kontekstual: Mempertimbangkan Realitas Kemajemukan Dalam Pendidikan Agama (Jakarta: BPK Gunung Mulia, 2010), 3334.

158 Ibid., 36-37. 
mempengaruhinya dan berusaha mengubahnya. Pada awalnya gerakan ini disebut New atau Neo-Evangelical, kemudian disingkat menjadi "Evangelical" (Injili), yang dipimpin oleh Harold Ockenga. Semua organisasi yang tergabung dalam gerakan Injili ini terorganisir dalam satu lembaga yang disebut National Association of Evangelicals (NAE) yang didirikan tahun 1942.

2. Kaum Injili kurang terlibat dalam dialog antar umat beragama disebabkan beberapa hal, yaitu: kuatir akan terjadi sinkretisme melalui dialog antar umat beragama; kuatir akan disalahmengerti mengenai keterlibatan dalam dialog antara umat beragama; dialog tidak dibutuhkan dalam penginjilan, yang dibutuhkan adalah pendampingan pastoral Kristen; kuatir akan terjadinya kemunduran dalam penginjilan jika melakukan dialog antar umat beragama; kurangnya keterlibatan kaum Injili dalam dialog antar umat beragama akan menghambat upaya saling menghargai antar umat beragama; dan kurangnya keterbukaan kaum Injili terhadap berbagai metode dialog yang banyak dikembangkan di kalangan Kristen lain.

3. Ada beberapa metode yang dapat digunakan kaum Injili dalam melakukan dialog antar umat beragama yang dihasilkan melalui para pemikir Protestan dan Katolik, yaitu: dialog komunitas, dialog kehidupan, dialog karya, dialog teologis, dialog pengamalan keagamaan, dan dialog "passing over".

4. Metode dialog "passing over" ditolak oleh kebanyakan kaum Injili, tetapi sebenarnya metode ini dapat digunakan apabila disertai pengetahuan yang cukup mengenai agamaagama lain dan iman yang kuat, serta sikap yang rendah hati (kenosis = mengosongkan diri).

5. Dalam pendidikan agama Kristen, dialog harus terus dikembangkan dalam bentuk percakapan agama-agama secara luas, untuk membentuk para naradidik yang memiliki keterbukaan, penghargaan, dan kerjasama yang baik dengan para penganut agama lain. Untuk itu, pendidikan agama Kristen harus mempertimbangkan model dialog yang cocok dengan konteks yang sedang berlangsung.

Sesuai dengan uraian pembahasan di atas, maka penulis memberi saran-saran sebagai berikut:

1. Setiap penyelenggara PAK harus konsisten dalam mengembangkan dialog dalam pembelajaran sehingga para naradidik terbiasa bercakap-cakap secara kritis dan terbuka kepada perbedaan pandangan dan keyakinan. 
2. Setiap pendidik harus memberi teladan dalam berdialog dengan memperlihatkan kecakapan dalam berbicara dan berpikir yang dialogis, khususnya menyangkut keberagaman agama.

3. Pendidikan agama harus memberi ruang yang cukup luas untuk mempercakapkan keberagaman agama dengan mempertimbangkan model dialog yang kontekstual. 


\section{Daftar Pustaka}

Antone, Hope S. Pendidikan Kristiani Kontekstual: Mempertimbangkan Realitas Kemajemukan Dalam Pendidikan Agama (Jakarta: BPK Gunung Mulia, 2010).

Athyal, Saphir Philip, “The Uniqueness and Universality of Christ dalam The New Face of Evangelicalism: An International Symposium on the Lausanne Covenant, ed. C. Rene Padila (London: Hodder and Stoughton, 1979).

Browning, W.R.F., Kamus Alkitab (Jakarta: BPK Gunung Mulia, 2007).

Clarke, Harr E \& Lucinda R. Summers (eds.), The New Grolier Webster International Dictionary of the English Language. (New York: Grolier Inc, 1976).

D’Amico, David F., "Southern Baptists \& American Evangelicals: A Common Mission? Dalam David S. Dockery (ed.), Southern Baptists \& American Evangelicals: The Conversation Continues (Nashville: Tennessee: Broadman \& Holman Publishers, 1993).

Departemen Pendidikan dan Kebudayaan, Kamus besar bahasa Indonesia (Jakarta: Balai Pustaka, 1996).

Ellingsen, Mark, The Evangelical Movement: Growth, Impact, Controversy, Dialog (Minneapolis: Augsburg Publishing House, 1988).

Hesselgrave, David J., "Traditional Religions, New Religions, and the Communication of the Christian Faith" dalam Irving Hexham, Stephen Rost, John Morehead, John W. Morehead II (eds.), Encountering New Religious Movements: A Holistic Evangelical Approach (Grand Rapids, Michigan: Kregel Publication Inc., 2004).

Iguassu Affirmation. $\quad$ http://www.christianitytoday.com/ct/1999/novemberwebonly/13.0.html?start=5. November (Web-only) 1999, Vol. 43 (diakses 5 Oktober 2017).

Kenosis. http://alkitab.sabda.org/dictionary.php?word=Kenosis (diakses 5 Oktober 2017).

Manila Manifesto, http://www.lausanne.org/en/documents/manila-manifesto.html (diakses 5 Oktober 2017). 
Netland, Harold A., Dissonant Voices: Religious Pluralism and the Question of Truth (USA: Wm. B. Eerdmans Publishing Co., 1991).

Noer, Kautzar Azhari, "Passing over": Memperkaya Pengalaman Keagamaan”, Dalam Hidayat, Komaruddin \& Ahmad Gaus AF, Passing Over: Melintasi Batas Agama (Jakarta: Penerbit PT Gramedia Pustaka Utama, 1998).

Pinnock, Clark H. 1990. "Toward An Evangelical Theology of Religions. JETS 33/3 (September 1990), 359-368. http://www.etsjets.org/files/JETS-PDFs/33/33-3/33-3pp359-368_JETS.pdf (diakses 5 Oktober 2017).

Riyanto, E. Armada. Dialog agama dalam pandangan Gereja Katolik (Yogyakarta: Kanisius. 1995).

Riyanto, E. Armada. Dialog interreligius: Historisitas, Tesis, Pergumulan, Wajah (Yogyakarta: Kanisius. 2010).

Samuel, Vinay \& Chris Sugden, "Dialogue with Other Religions: An Evangelical View". Dalam Bong Rin Ro \& Ruth Eshenaur (eds.), The Bible \& Theology in Asia Contexts: An Evangelical Perspective on Asia Theology (Seoul, Korea: Word of Life Press \& Asia Theological Association, 1984).

Schumann, Olaf H., Dialog Antar Umat Beragama (Jakarta: BPK Gunung Mulia, 2008).

Sejarah PGLII. http://www.pglii.org/tentang/sejarah.htm (5 Oktober 2017).

Sitompul, Einar M., Gereja Menyikapi Perubahan (Jakarta: BPK Gunung Mulia, 2004).

Stott, John, The Lausanne Covenant: An Exposition and Commentary (Minneapolis, Minnesota: World Wide Publications, 1975).

Stott, John (ed.). Making Christ Known: Historic Mission Documents from the Lausanne Movement 1974-1989 (Carlisle, Cumbria: Paternoster Press, 1996).

The Lausanne Covenant, http://www.lausanne.org/en/documents/lausanne-covenant.html. (diakses 5 Oktober 2017).

World Council of Churches. Guidelines on Dialogue with People Living Faiths and Ideologies (Geneva: World Council of Churches, 1979). 